\title{
PARA UNA CRÍTICA DE LA VIOLENCIA DEL DERECHO CIVIL
}

\section{FOR A CRITIQUE OF THE CIVIL LAW'S VIOLENCE}

\author{
Ronald Zuleyman Rico Sandoval* \\ Fecha de recepción: 6 de febrero de 2009 \\ Fecha de aceptación: 19 de abril de 2010
}

\footnotetext{
* Abogado de la Pontificia Universidad Javeriana. Diplomado en Derecho Constitucional de la misma Universidad. Ex auxiliar de magistrado, Sala Civil del Tribunal Superior de Bogotá.

Correo electrónico: ronaldzrico@yahoo.com.
} 


\section{RESUMEN}

La violencia se encuentra presente en el derecho desde su emergencia, esto es, desde que el animal humano se convierte en animal social. Dicha violencia permanece en todas las facetas del derecho, incluida el área civil, como violencia conservadora a la cual se le puede oponer una violencia pura con potencialidad de articular una nueva subjetividad social. Sin embargo, para entender la violencia del derecho debe rastrearse hasta el núcleo mismo de la subjetividad humana como base de la sociedad, y para ello una mirada al psicoanálisis se presenta como una propuesta transdisciplinaria para el estudio de la ciencia jurídica.

Palabras clave: violencia, ley, goce, real, simbólico, imaginario, sinthome, homo sacer, amor, Kant, Freud, Lacan, Zizek, Benjamin, Cover, Agamben, Deleuze.

Palabras clave descriptor: Derecho civil, violencia (Derecho), historia y crítica.

\section{ABSTRACT}

The violence is present in the law since its emergence; this is, since the human animal becomes a social animal. Such violence is present in all facets of law, including civil law, as conservative violence to which we can oppose a pure violence with potentiality to articulate a new social subjectivity. However, to understand the violence of the law, we need to search into the very core of human subjectivity as the basis of society. We present a look at the psychoanalysis as a transdiscipline proposal for the study of legal science.

Key words: violence, law, enjoy, real, symbolic, imaginary, sinthome, homo sacer, love, Kant, Freud, Lacan, Zizek, Benjamin, Cover, Agamben, Deleuze.

Key word plus: Civil law, Violence (Law), Law, History and criticism. 


\section{INTRODUCCIÓN}

La tarea de una crítica del derecho debe empezar por describir aquellos intersticios donde el derecho parece no serlo. Esta frase no es extraña para muchos, y marca, por el contrario, el camino de este ensayo, el de los límites del derecho y en particular del derecho civil.

Para una verdadera crítica de un objeto de estudio, es indispensable interesarse por las condiciones de posibilidad de ese objeto, más que por él mismo, así como por el establecimiento de sus propios límites, lo que conduciría a la elaboración de un juicio. ¿Qué es lo que hace posible, para ilustrar mi posición, el derecho de propiedad?, ¿qué es lo que hace posible que por vía judicial se haga respetar el derecho de propiedad?, y ¿qué es lo que hace posible que se pueda afirmar que existe un respeto a la figura de autoridad del juez, para que se cumpla la orden de hacer respetar el derecho de propiedad?

Las condiciones de posibilidad se encuentran enmarcadas en el ámbito de desempeño del derecho. Es decir, en las condiciones de eficacia que posibilitan al derecho existir, por lo tanto, una crítica del derecho no se enmarca en el ámbito de los fines (por ejemplo, la justicia) sino de los medios que utiliza, y en consecuencia, deben buscarse dentro de un límite espacial. Por ello resulta importante destacar los límites del derecho, aquellos espacios en donde el derecho comulga con la violencia de "la justicia por la propia mano". Nótese acá que la relación entre el derecho y la violencia, como se señalará más adelante, es ambigua en determinados aspectos, puesto que al decir del abuso del derecho, y la justicia por la propia mano, debe reflexionarse que siempre en los casos considerados como no jurídicos, éstos se expresan de todos modos en términos jurídicos.

Sigo aquí, como puede leerse entre líneas a KANT en su Crítica, pero quiero llegar más allá, donde éste se cruza con SADE, tal como lo evidenció LACAN al decir que la verdad de la ley universal kantiana debe buscarse en ese oscuro suplemento sadeano de la ley1. Quiero decir que reconocer la verdad del derecho, o su esencia, implica avanzar hasta demostrar lo que éste reprime: su violencia innata.

En este ensayo quiero pensar el derecho como un dispositivo violento que puede ser usado por las máquinas sociales y las máquinas deseantes, esto es, por los sujetos de derecho insertos en la sociedad que luchan por la administración del goce, las primeras, y por la satisfacción del deseo propio, las segundas. Para estas últimas, las máquinas deseantes, la violencia conservadora del derecho puede ser utilizada, mediante la reapropiación del lenguaje

1 Véase Jacques Lacan, "Kant con Sade”. En Escritos 2. Traducción de Tomás Segovia. Págs. 744 a 770. Siglo XXI editores. Argentina. (2003). 
jurídico, para abrir espacios de luchas sociales que permitan la articulación de nuevas subjetividades sociales.

Para demostrar lo anterior, argumentativamente seguiré el siguiente curso: en primer lugar acudiré a conceptualizaciones propias del psicoanálisis y la filosofía a efectos de estructurar un marco crítico de la violencia en general; lo anterior será brevemente acoplado con significaciones propias del derecho civil, para en seguida tratar de evidenciar cómo el derecho se estructura como un dispositivo maquínico de violencia.

Debe decirse que la referencia al psicoanálisis no es arbitraria. Téngase en cuenta que dicha ciencia estudia al sujeto, en sí, y en cuanto al lugar que ocupa en la sociedad. Por ello, si el punto nodal de la sociedad es el individuo, los análisis que sobre el individuo aporta el psicoanálisis resultan relevantes para comprender la realidad social. En este sentido la conceptualización psicoanalítica provee un marco teórico válido en derecho, dado que esta es una ciencia que regula al individuo en sociedad ${ }^{2}$.

\section{DE LA VIOLENCIA CREADORA Y DE LA CONSERVADORA DEL DERECHO}

En un escrito que data de 1932, Sigmund Freud expuso la relación entre el derecho y la violencia como una correspondencia rastreable hasta los "orígenes arcaicos de la humanidad", según la cual la primera es producto de la segunda. Señala FREUd cómo los conflictos primitivos se solucionaban acudiendo a la fuerza, como sucede en el "reino animal", y el que triunfaba era el que se quedaba con las cosas, el que decía jesto es mío! ${ }^{3}$ El objetivo de la lucha siempre es el mismo, "(...) por el daño que se le inflige o por la aniquilación de sus fuerzas, una de las partes contendientes ha de ser obligada a abandonar sus pretensiones o su oposición. Este objetivo se alcanza en forma más completa cuando la fuerza del enemigo queda definitivamente eliminada, es decir, cuando se lo mata. Tal resultado ofrece la doble ventaja de que el enemigo no puede iniciar de nuevo su oposición y de que el destino

2 Acá a modo de nota marginal valga la pena citar a CosTAs DouzINAs cuando dice "El psicoanálisis, la bonanza de los últimos tiempos en el pensamiento social, es predominantemente una teoría de la objetividad y la legalidad. El derecho es el cimiento de la subjetividad y el cemento de la sociabilidad y, tal y como insisten Jacques Lacan y su herético discípulo Pierre Legendre, ni los individuos ni las sociedades pueden escapar a su imperio con impunidad." El fin de los derechos humanos. Traducción de Óscar Guardiola-Rivera, Ricardo Sanín Restrepo \& Ómar Alonso Medina. Pág. 357. Legis. Universidad de Antioquia. Colombia. (2008). La lista de filósofos que han advertido la relación entre psicoanálisis y el derecho es aún más larga, pero bástenos, por ahora, la anterior referencia, ya que en este ensayo se sigue, también, otro autor que se citará más adelante, SLAvoJ ZizeK.

3 Costas Douzinas, siguiendo a JEAnNe SCHOREDER, en clara estructuración hegeliana sobre el deseo y la relación del sujeto en la sociedad, sostiene que la propiedad cumple una función importante que es la construcción de la subjetividad. Luego cuando un sujeto manifiesta que ostenta la propiedad de un bien, no sólo está recalcando su poderío sobre el objeto, sino su lugar en la sociedad. Ob. cit. Págs. 336 a 342. 
sufrido sirve como escarmiento, desanimando a otros que pretendan seguir su ejemplo. (...)"4.

Conforme a lo anterior, la categoría violencia puede definirse como el uso de mecanismos o dispositivos tendientes a doblegar el deseo del otro. Por mecanismos de violencia entiendo tanto actos como argumentos tendientes a la aniquilación de las pretensiones del sujeto violentado ${ }^{5}$.

Volviendo a FreUd, tal estado de cosas se da hasta que las personas se dan cuenta de la fuerza mayor de la comunidad frente a la del individuo. "(...) La violencia es vencida por la unión; el poderío de los unidos representa ahora el derecho, en oposición a la fuerza del individuo aislado. Vemos pues que el derecho no es sino el poderío de una comunidad. Sigue siendo una fuerza dispuesta a dirigirse contra cualquier individuo que se le oponga; recurre a los mismos medios, persigue los mismos fines; en el fondo, la diferencia sólo reside en que ya no es el poderío del individuo el que se impone, sino el de un grupo de individuos. (...)". Pero para que ello funcione, la violencia de la "unión" debe tener vocación de permanencia, concluye FreUd, toda vez que si la comunidad se disuelve, cualquiera puede intentar imponer su voluntad, luego el derecho ahora creado debe poder perdurar ${ }^{6}$.

Dicha estructura de la vida social ya había sido expuesta en otro texto de 1930, El malestar en la cultura, en donde FREUD reconoce que "(...) La vida humana en común sólo se torna posible cuando llega a reunirse una mayoría más poderosa que cada uno de los individuos y que se mantenga unida frente a cualquiera de éstos. El poderío de tal comunidad se enfrenta entonces, como "Derecho", con el poderío del individuo, que se tacha de "fuerza bruta". Esta situación del poderío individual por el de la comunidad representa el paso decisivo hacia la cultura. Su carácter esencial reside en que los miembros de la comunidad restringen sus posibilidades de satisfacción, mientras que el individuo aislado no reconocía semejantes restricciones. Así, pues, el primer requisito cultural es el de la justicia, o sea la seguridad de que el orden jurídico, una vez establecido, ya no será violado a favor de un individuo, sin que esto implique un pronunciamiento sobre el valor ético de semejante derecho. El curso ulterior de la evolución cultural parece tender a que este derecho deje

4 Sigmund Freud. "El porqué de la guerra". En Obras completas. Tomo III. Pág. 3208. Editorial Biblioteca nueva. Traducción de Luis López-Ballesteros.

5 Siguiendo a Freud, un acto violento puede ser el uso de la fuerza para doblegar al otro. No obstante, la argumentación como mecanismo violento no requiere per se el empleo de fuerza física, por lo que puede ser leído en el sentido que Ernesto Laclau le da al término hegemonía, es decir, como la lucha en la cual una significación particular encarna un significante universal y vacío, de tal suerte que dicha encarnación tienda a ser reconocida por los sujetos integrantes de la sociedad como propia. Del autor véase "Identidad y hegemonía: el rol de la universalidad en la constitución de lógicas políticas". En Butler, LAClau, ZIZEK. Contingencia, hegemonía, universalidad. Diálogos contemporáneos en la izquierda. Págs. 49 a 93. Fondo de Cultura Económica. Argentina. (2004). Traducción de Cristina Sardoy \& Graciela Homs.

6 Freud. "El porqué....". Pág. 3209. 
de expresar la voluntad de un pequeño grupo -casta, tribu, clase social debe decir social-, que a su vez se enfrenta, como individualidad violentamente agresiva, con otras masas quizá más numerosas. El resultado final ha de ser el establecimiento de un derecho al que todos -o por lo menos todos los individuos aptos para la vida en comunidad-hayan contribuido con el sacrificio de sus instintos, y que no deje a ninguno - una vez más: con la mencionada limitación-a merced de la fuerza bruta"7.

Hasta aquí no he expuesto nada ajeno al discurso político jurídico enseñado por generaciones, según el cual las sociedades primitivas vivían en desarmonía hasta que se implantaba un "contrato social" que venía a controlar las relaciones sociales de los individuos. Es, si se quiere, el punto nodal o el cortocircuito en el cual surge el derecho revolucionario de la libertad primitiva, para expresarlo en términos de HaURiou, que da paso al derecho estatal o sedentario ${ }^{8}$.

El punto aquí no es el de reescribir la historia de las ideas políticas desde el psicoanálisis, sino más bien reconocer la violencia fundadora del derecho e introducir la violencia conservadora, que es lo que permitirá esbozar una mirada al obsceno núcleo de la ley.

Para ello Freud puede seguir siendo el punto de apoyo. En el último ensayo citado ${ }^{9}$ expone que para la constitución de la sociedad todos los individuos han renunciado a parte de su goce y se lo han transferido al Estado a fin de que, autolimitándose y confiriéndole un poder especial a una instancia administradora de la fuerza o de la violencia, ésta sea la que controle y regule los instintos para evitar el daño al otro. El problema de esta transferencia es que el ser humano siempre va a sentirse incompleto, como si algo fallara, pues siempre existirá la impresión del poder disciplinante sobre sus hombros, que impide su plena satisfacción ${ }^{10}$. Al decir de SADE, la revolución francesa, que vino a reconocer los derechos de todos los hombres, no reconoció el derecho al goce propio, por ello la libertad conferida por el Estado es una libertad limitada, nunca plena ${ }^{11}$.

7 Sigmund Freud. "El malestar en la cultura". En El malestar en la cultura y otros ensayos. Pág. 39. Traducción de Ramón Rey Ardid. Alianza Editorial. Colombia, (1988).

8 La referencia debe ser aquella que va más allá de las teorías contractualistas de Rousseau y Sieyès, por ello valdría la pena hacer una revisión a la literatura jurídica que reivindica las manifestaciones revolucionarias populares como fuerzas creadoras del derecho. La expresión de MAURICE HAURIOU es expuesta por el argentino Jorge Reinaldo A. VAnossi, en su Teoría Constitucional, donde sigue, entre otros autores, en el capítulo destinado a la conceptualización del poder constituyente, al francés en su libro Derecho público y constitucional. Tomo I. Vanossi. Teoría constituyente, poder constituyente fundacional, revolucionario, reformador. Ediciones Desalma. Buenos Aires. (1975).

9 "El malestar en la cultura". En El malestar en la cultura y otros ensayos...

10 Dicha ansiedad de los sujetos puede verse en Matrix, la película de ciencia ficción de los hermanos Wakosky, en donde el protagonista, un empleado de oficina común y corriente, subvierte su propia identificación en la internet, puesto que la "realidad" se le presenta como "irreal" (en el sentido de carente de lo real).

11 Sigo en este punto lo expuesto por el filósofo y psicoanalista francés JACQUES LACAN, en su ensayo 
Allí mismo reside el malestar en la cultura, pues siempre existirá frente al Estado una pulsión permanente que impulsa a los sujetos asociados a buscar su satisfacción particular y, por ende, a transgredir las leyes que los someten. Dicho sometimiento no se presenta solamente en un Estado totalitario que reprime a los asociados, pues como lo reconoce SLAVOJ ZiZEK, el control disciplinante se puede encontrar en las regulaciones establecidas para calmar el goce de los asociados, y no para satisfacerlo, como en el caso del fumador que se le permite fumar, pero su fuente material de placer se encuentra sometida a un sinnúmero de regulaciones y restricciones que van desde el cigarrillo sin nicotina (para que el fumador no se haga daño a sí mismo), hasta la delimitación de escenarios donde se puede fumar ${ }^{12}$.

Si somos justos con FreUd, entonces tenemos que reconocer, tal y como lo hizo él, que en la vida cultural del ser humano, éste se desarrolla en medio de la lucha entre su deseo y su represión. Originalmente el hombre vivía en libertad y así intentaba satisfacer sus deseos, pero luego vino otro sujeto -la sociedad, la cultura- que llegó a impedir dicho goce limitándolo en beneficio de la comunidad. O como dice San Pablo en la epístola a los Romanos, antes de la ley yo vivía tranquilo, después de la ley, yo vivía en pecado ${ }^{13}$.

Entonces, debemos concluir que para la vida en comunidad es necesaria una renuncia a una porción de goce individual, y por ello, siguiendo la conceptualización establecida previamente, la violencia se presenta en el punto genitor del derecho.

Ahora sí, ante dicha pulsión no le queda otra salida al Estado que regular, controlar y en caso dado, castigar. El malestar, entonces, se presenta en la constante relación entre pulsión y dominación que subyace al derecho.

La narración de los orígenes no es ajena tampoco al entorno jurídico penal, que desde hace más de 200 años conoce el texto de BECCARIA sobre los delitos y las penas. En dicha obra se expone que "Las leyes son las condiciones bajo

\footnotetext{
"Kant con Sade" ya citado. De este texto valga la cita siguiente sobre "las libertades que la revolución acaba de promulgar en su nombre": "Pues si consideramos los derechos del hombre bajo la óptica de la filosofía, vemos aparecer lo que por lo demás todo el mundo sabe ahora de su verdad. Se reducen a la libertad de desear en vano". (Pág. 764). También puede verse, entre otras muchas obras, el acápite II, del capítulo 5 "Está bien todo lo que termina bien?” de la parte tercera Cum grano praxis, de SAlvoj Zizek. En Porque no saben lo que hacen, el goce como factor politico. Traducción de Jorge Piatigorsky. Paidós. Argentina. (1998).

12 Otro ejemplo viene a ser el padre que mediante la manipulación del deseo, inculca en el hijo el sentimiento de culpa frente a cualquier situación, dirigiendo su deseo hacia su propio objetivo. Este padre es aún más totalitario que el que impone las reglas. Esta paradoja del deseo y el superyó es expuesta por Slavoj ZizeK de la siguiente forma: “(...) Como contraste, el mensaje del amo totalitario es: 'Sé mejor que tú mismo lo que quieres de verdad, lo que es mejor para tus intereses, y, por eso, lo que te mando que hagas es lo que tú, en lo profundo de ti mismo, deseas realmente, sin darte cuenta, incluso si superficialmente pareces estar en contra de ello!'.” En El frágil absoluto o ¿Por qué merece la pena luchar por el legado cristiano? Pág. 174. Traducción de Antonio Gimeno. Ed. Pre-textos. Valencia. España. (2002).
}

13 Romanos 7: 7, 11 
las cuales hombres aislados e independientes se unieron en sociedad, cansados de vivir en un continuo estado de guerra, y de gozar una libertad que les era inútil por la incertidumbre de conservarla. Sacrificaron por eso una parte de ella para gozar del resto en absoluta tranquilidad. La suma de todas estas porciones de libertad, sacrificadas al bien de cada uno, forma la soberanía de una nación, y el soberano es su administrador y legítimo depositario. Pero no bastaba formar este depósito, era necesario también defenderlo de las usurpaciones privadas de cada hombre en particular que procura no sólo quitar del depósito la porción propia, sino usurparse las ajenas. Para evitar estas usurpaciones se necesitaban motivos sensibles que fuesen bastantes a contener el ánimo despótico de cada hombre cuando quisiere sumergir las leyes de la sociedad a su caos antiguo. Estos motivos sensibles son las penas establecidas contra los infractores de aquellas leyes. (...)”; y más adelante añade “(...) El agregado de todas esta (sic) pequeñas porciones de libertad posibles forma el derecho de castigar; todo lo demás es abuso, y no justicia: es hecho, no derecho"14.

BECCARÍA también reconoce, al igual que Freud, que la relación entre el derecho y la violencia (o fuerza) es tal que "aquella es una modificación de ésta"15. Costas Douzinas lo expresa de la siguiente forma: "Las comunidades se mantienen unidas por los lazos emocionales comunes y por la violencia. La incapacidad del derecho para resolver los conflictos en una comunidad donde no se comparten ni sentimientos ni relaciones emocionales conlleva al amplio uso de la violencia jurídica. (...)"16.

Si de puntos de apoyo argumentativos se trata, sirve también para entrelazar el derecho con la hipótesis conjetural freudiana, traer a colación a HaNS Kelsen, paradigma del derecho privado en Colombia. Kelsen, al tratar de definir el concepto de derecho, parte del supuesto de que la conducta humana como objeto de regulación normativa debe ser dirigida para provocar una conducta socialmente deseada. Ello se logra mediante el obedecimiento, el cual puede ser voluntario o generarse mediante la coacción. Coacción que se presenta de forma directa mediante la coerción, o de forma indirecta mediante el otorgamiento de una recompensa (o beneficio). En este espectro sitúa Kelsen, en su Teoría general del derecho y del Estado de 1945, el derecho como una técnica social específica de un orden coactivo que paradójicamente se comporta como el acto que desea reprimir, esto es, de forma violenta:

"Entre las paradojas de la técnica social que hemos caracterizado como orden coactivo se encuentra el hecho de que su instrumento específico, el acto coercitivo de la sanción, es exactamente de la misma especie que el que trata

14 Cesare Beccaria. De los delitos y de las penas. Págs. 9 a 11. Textos fundamentales de derecho, núm. 2. $3^{\mathrm{a}}$ ed. Universidad Externado de Colombia. Bogotá. (1995).

15 Ibid.

16 Ob. cit. Pág. 361. 
de prevenir en las relaciones de los individuos, esto es, el acto antijurídico; pues la sanción contra la conducta perjudicial es también conducta. Aquello que debe obtenerse mediante la amenaza de una privación forzada de la vida, la salud, la libertad o la propiedad, es precisamente que los hombres en su actividad recíproca se abstengan de privarse por la fuerza uno a otro de la vida, la salud, la libertad o la propiedad. La fuerza es empleada para prevenir el empleo de la fuerza en la vida social. Esto parece ser una antinomia; y el esfuerzo para evitarla conduce a la doctrina del anarquismo absoluto que proscribe la fuerza, incluso como sanción. El anarquismo tiende a establecer el orden social exclusivamente sobre la base de la obediencia voluntaria de los individuos. Tal doctrina rechaza la técnica de un orden coercitivo y, por tanto, repudia al derecho como forma de organización"17.

\section{DE FREUD A LACAN, Y RETORNO A FREUD}

Por otro sesgo debemos asomarnos, necesariamente, a LACAN. Primeramente debe recordarse que en la estructuración sociológica de FreUd, éste sitúa la creación del derecho en un "crimen absoluto" que él presenta en la forma del parricidio original. En Tótem y tabú se narra que la asociación de la comunidad para contrarrestar la violencia individual de quien toma en posesión lo que los demás desean, se da cuando el padre original que detenta a todas las mujeres con exclusión de los demás hombres, es asesinado por sus hijos, para que ellos puedan acceder a la propiedad que ha sido controlada por aquél. Con el parricidio primigenio, los hijos implantan la ley, por virtud de la cual nadie puede matar (es decir, prohíbe su excepción, además de prohibir el incesto) $)^{18}$.

Esa implantación de la ley que prohíbe matar es lo que el psicoanálisis denomina el sentimiento de culpa que estatuye a la ley ${ }^{19}$. Así nace la sociedad y el derecho, según FreUd.

Dicha estructuración, por carecer de fundamentos etnológicos ni antropológicos fue criticada desde muchos sectores -como es bien sabido-, aun cuando, como he destacado con referencias anteriores, para la teoría

17 Hans Kelsen. Teoría general del derecho y del Estado. Pág. 24. Universidad Nacional Autónoma de México. Traducción de Eduardo García Máynez. México. (1995). En igual sentido véase el capítulo III. "El concepto del derecho y la teoría de la proposición jurídica" de la Teoría pura del derecho, originalmente publicada en 1935. Editorial Losada S.A. Traducción de Jorge G. Tejerina. Buenos Aires. (1941).

18 Sigmund Freud. "Tótem y tabú". En Obras completas. Tomo II. Págs. 1838 a 1839. Traducción de Luis López Ballesteros. Biblioteca Nueva. (1973). Dice Freud que "Los hermanos expulsados se reunieron un día, mataron al padre y devoraron su cadáver, poniendo así un fin a la existencia de la horda paterna", y más adelante continúa, "De este modo es como la conciencia de la culpabilidad del hijo engendró los dos tabúes fundamentales del totemismo, los cuales tenían que coincidir con los deseos reprimidos del complejo de Edipo".

19 Este superyoico sentimiento de culpa se denomina el nombre-del-padre, o el retorno-del-padre. 
jurídica ${ }^{20}$ siempre ha estado claro que el derecho surgió de un pacto social violento para evitar la violencia de un individuo. Sin embargo, el retorno a FREUD que promulgó JACQUES LACAN se dirigió a relievar la importancia de la estructura o matriz ya descrita, según la cual el sujeto interioriza la ley del padre primitivo que instaura la prohibición, es decir, que los individuos aceptan dicha ley, y es por su sumisión a la misma que el ser humano se estructura como un sujeto deseante, inmerso en una sociedad ${ }^{21}$.

Explico lo anterior. La matriz lacaniana de la realidad, que tiene como trasfondo el parricidio edípico o primordial, se basa en la interrelación de tres registros o estadios que juntos posibilitan la estructuración de la identidad del sujeto, ellos son: lo imaginario, lo simbólico y lo real. Lo imaginario es la primera etapa de reconocimiento propio del sujeto en la imagen externa a él y que percibe, no solo mediante su reflejo, sino además, por la imago que obtiene de su reflejo en otros (su madre, i. e.). Su inclusión en el registro simbólico, que es el del lenguaje, y por ende el del derecho, se da mediante la ley del padre, esto es, el nombre del padre se postula como la instancia de la ley (que viene a prohibir el incesto y también el parricidio), mediante la identificación del sujeto con la posición de poder, es decir, la del falo. "Pero un residuo que no puede simbolizarse de la unión primitiva con el cuerpo materno, llamado lo real por LACAN, sobrevive a esta entrada al mundo de los signos (...) lo que queda de lo Real después de su prohibición por lo simbólico, es el secreto interior o 'núcleo' del sujeto: crea una presión incesante y destructiva para regresar a la unión primitiva (el vértigo hacia la muerte) que al mismo tiempo produce un poderoso placer obsceno, o jouissance"22.

La entrada al estadio simbólico es, siguiendo a Freud, el paso que el sujeto da al renunciar a un pedazo de su goce. La identificación imaginaria le permite establecer oposiciones del estilo schmittiano de amigo/enemigo, es decir, los que son como el sujeto y los que no lo son. La presión interna de lo real es lo que impulsa al sujeto a desear objetos de deseo (objet petit a en la terminología lacaniana) para llenar ese vacío de la pérdida de goce. Y a su vez, esta incesante búsqueda de objet petit $a$ es lo que genera en los sujetos la envidia y el odio.

Esta búsqueda del objet petit a conduce "a una competencia intensa por el objeto de amor y causan hostilidad, agresión y guerra" ${ }^{23}$.

La envidia, según LACAN, “(...) suele provocarla comúnmente la posesión de bienes que no tendrían ninguna utilidad para quien los envidia, y cuya

20 Por teoría jurídica pienso en el concepto de "alta teoría" enunciado por DiEgo EdUARdo LóPEZ Medina, como teoría de teóricos o teoría de eruditos. Véase Teoría impura del derecho. Ed. Legis. Bogotá. (2004).

21 Sigo en este acápite, muy de cerca, los análisis de Costas Douzinas en su libro ya citado. Capítulo 11. "El psicoanálisis a la medida del derecho: derechos y deseos". Págs. 357 a 383.

22 Ibid. Pág. 365.

23 Douzinas. Ob. cit. Pág. 371. 
verdadera naturaleza ni siquiera sospecha" ${ }^{24}$. La envidia se puede dar entre iguales (imaginarios), en tanto que el odio se presenta entre desiguales, esto es, con los que no forman parte del círculo social simbólico (los que no son el prójimo). Lo que se odia es la forma como el otro tiene una relación diferente con su goce, y a quien se odia es a ese otro, el extraño o extranjero.

La lucha por el objeto de deseo y por la unificación de la administración del goce se da en el plano simbólico, es decir, el de las relaciones sociales, el de la cultura, el lenguaje y el derecho. Pero también puede estar atravesado por lo real, (el espacio de la realidad que no cabe en la identificación simbólica, ni en la imaginaria), representado en estallidos de violencia fáctica, por oposición a la reglada o jurídica ${ }^{25}$.

En el intersticio entre lo real, lo imaginario y lo simbólico se sitúa el goce (jouissance en lacanés), referente frente al cual se estructura el deseo del sujeto. Pero este núcleo es un plus, algo que excede al goce no cedido, y representa al goce entregado, en el sentido que con éste se completaría el sujeto. Completud imposible si se tiene en cuenta que el lugar de la jouissance es un lugar vacío, pero cuya cerrazón se presenta como un acto de fe, dado que el sujeto "cree" estar completo, gracias a la interrelación con el deseo. El sujeto siente una seguridad, por ello la armonización de los registros enunciados y el goce es lo que garantiza la consistencia del ser.

En otras palabras: el sujeto experimenta una identificación con su núcleo social al integrarse a éste y asumir las costumbres del grupo (referente imaginario) de tal suerte que odia cualquier otra manifestación diferente de administrar el goce, o envidia la relación que los extraños tienen con su jouissance, porque se la cree como una situación especial que pone en inferioridad el goce propio. Para que ello sea así el sujeto debe creer que su núcleo social es el correcto, pues de esta forma está estructurando su realidad. El derecho aquí, como parte integrante de la realidad, viene a zanjar en la relación amigo/enemigo, odio/amor, señalando los procedimientos en que los conflictos pueden solucionarse, regulando, por ejemplo, la forma de adquisición de la propiedad de cosas y castigando el hurto de ellas.

Pero en el trasfondo de esa realidad se sitúa el carácter obsceno del goce: el placer que se obtendría al satisfacer un deseo. Jouissance que no está escondida, puesto que es el referente del deseo. Si bien el goce se presenta en su relación con lo real, es decir, como una intrusión que desestabiliza al sujeto, la forma de éste para sobrellevarlo es simbolizándolo mediante un acto de repetición. Repetición que establece la ley reprimiendo el acto mismo de

24 JacQues Lacan. Seminario 11: los cuatro conceptos fundamentales del psicoanálisis. Pág. 122. Traducción de Juan Luis Delmont-Mauri y Julieta Sucre. Ed. Paidós. España. (1987).

25 Piénsese aquí en la reacción violenta del racista contra el negro (o el judío, o el extranjero), cuyo motivo es la condición misma del sujeto violentado. Ello es comentado por ZıZEK en La suspensión politica de la ética. Traducción de Marcos Mayer. Fondo de Cultura Económica. Argentina. (2005). 
repetición. En términos freudianos, el asesinato del padre establece la ley que prohíbe asesinar, pero la forclusión de dicha relación es lo que permite el establecimiento de una nueva sociedad con un nuevo derecho.

Otra vez: lo reprimido aquí no es el núcleo perverso, o para nuestro asunto, el origen violento del derecho, sino la articulación entre ese origen y su repetición mediante la ley. Dicha exposición no pretende demostrar la vacuidad del derecho sino la necesidad del mismo, puesto que la renuncia al goce y el establecimiento de una instancia superior que lo administre resulta necesario para la vida en sociedad. El derecho así no es natural, sólo necesario.

LACAN llama la articulación de la jouissance y los registros real, imaginario y simbólico, sinthome, neologismo que representa una formación significante penetrada de goce, esto es, la forma en que se organiza el goce de un sujeto (y de una sociedad), de tal suerte que posibilita la elección de un proceso identificatorio particular, es decir: permite escoger el permanecer en una sociedad particular o salirse de ella, lo que ZizeK denomina "evitar la locura", puesto que "(...) por medio de vincular nuestro goce a una determinada formación significante, simbólica, (se) asegura un mínimo de congruencia a nuestro ser-en-el-mundo"26.

De lo anterior puede concluirse la importancia que para el psicoanálisis lacaniano tiene el sinthome, dado que gracias a él podemos tener una conciencia de realidad. Por ello LACAN apuesta por la identificación del sujeto con el sinthome, esto es, con la forma como articula su deseo en sociedad, con el elemento que garantiza la consistencia del sujeto, con aquello que es en el sujeto más que sí mismo ${ }^{27}$.

\section{DE LA VIOLENCIA CONSERVADORA AL HOMO SACER}

WALTER BENJAmin en un texto de $1921^{28}$ problematiza la relación entre derecho y violencia. Para ello establece una diferenciación teórica: existe una violencia que llama mítica en contraposición a otra "pura", "revolucionaria", designada como divina. La violencia mítica es en esencia estatal, puesto que la divide en la violencia fundadora, que crea el derecho, y la violencia conservadora que sostiene o le da permanencia al derecho. Por su parte, la violencia divina la posiciona como no estatal, esto es, aquella que no proviene del "sujeto Estado" al cual se le ha asignado la potestad de administrar la violencia (en el sentido en que BECCARIA y KeLSEN la reconocen), pero que en igual sentido

26 Slavoj Zızek. El sublime objeto de la ideología. Pág. 111. Traducción de Isabel Vericat Núñez. Siglo XXI Editores. Argentina. (2003).

27 Sobre el particular ver SLAVOJ ZIZEK. Mirando al sesgo. Una introducción a JACQUES LACAN a través de la cultura popular. Traducción de Jorge Piatigorsky. Paidós. Argentina. (2004).

28 Ver "Para una crítica de la violencia". En Para una crítica de la violencia y otros ensayos. Iluminaciones IV. Traducción de Roberto Blatt. Editorial Taurus. España. (1999). 
tiene la posibilidad de recrear la violencia fundadora e instaurar un nuevo orden jurídico.

Como se ha esbozado brevemente, en el origen de todo derecho existe un plus, un je ne sais quois del derecho que irrumpe en forma de violencia, $\mathrm{y}$ que deriva en una administración de violencia. En este sentido debe pensarse siempre que si alguna vez se constituyó el Estado por un brote de violencia revolucionaria, dicha potencia reformadora del Estado está latente permanentemente, y se puede presentar en cualquier momento. Piénsese, si se quiere, en los movimientos emancipadores del siglo XIX en América Latina, y piénsese también, en las luchas subversivas que buscaban la eliminación del statu quo actual y la implantación de un nuevo orden jurídico económico.

Por ello el Estado, para asegurar su permanencia, como lo afirma FREUD, debe tomarse para sí el monopolio de la fuerza ${ }^{29}$, es decir, de la violencia, y evitar que cualquiera pueda utilizar dicha fuerza creadora o destructora, para desestabilizar el "orden". "El Estado teme esta violencia", dice BENJAMIN, "por ser fundadora de derecho" 30.

Pero esta violencia que tiende a conservar el derecho irrumpe en el escenario jurídico estableciendo reglas mediante las cuales se ha de asegurar la permanencia del Estado, y por ende, la primera prohibición que debe efectuar es la del "crimen absoluto", es decir, la de la violencia fundadora ${ }^{31}$.

"Una vez más, el secreto traumático sobre el cual está sustentado el orden simbólico es el carácter violento sobre el cual éste se funda. En este caso el secreto de la violencia se oculta tras la legalidad que otorga retroactivamente la nueva ley, y se afianza en la paradoja del 'yo sí...pero ustedes no', es decir, yo sí actué de determinada forma violenta para acceder al poder y cambiar (el Estado), pero de ahora en adelante ya no se puede y solo se podrá acceder al poder (o cambiar el Estado o su constitución) por medio del procedimiento establecido en la ley.

"La figura aquí ejemplar es la del 'caníbal' que prohíbe el canibalismo. La historia simbólica rescribe el pasado en forma retroactiva, de tal manera que con la aparición de un 'nuevo vocabulario descriptivo' se reprime el exceso traumático de su propia violenta imposición ${ }^{32}$, de tal forma que el caníbal que elimina el canibalismo, mediante la introducción de nuevos significantes pueda subsumir su propia condición de caníbal.

29 La expresión “monopolio de la fuerza", muy común en el entorno jurídico, debe leerse, en el sentido que lo hace FrEUD, como el monopolio que tiene el Estado de la violencia, al igual que en otras épocas tuvo el monopolio del tabaco y la sal. SLAVou Freud. "Consideraciones de actualidad sobre la guerra y la muerte”, en El malestar en la cultura y otros ensayos. Ob. cit. Pág. 101.

30 Ibid. Pág. 29.

31 Sigmund Freud. Tótem y tabú.

32 En el texto citado se sigue a SALvoJ ZIZEK. En El frágil absoluto. Págs. 87 a 92. 
"Ese acto represor es el crimen absoluto, pero su naturaleza 'criminal', su rostro horroroso (ominoso) no radica en la forma en que es presentado, sino en su cercanía al 'reino de la Ley" ${ }^{63}{ }^{\prime \prime 34}$.

Este nuevo derecho no sólo regula la forma en que se han de efectuar los cambios estructurales del Estado, sino que tiende a regular y administrar toda forma de violencia. Por ello además de impartir violencia, verbi gratia, al aplicar la pena de muerte, que es el ejemplo más recurrente, también regula la forma en que otros sujetos pueden pactar formas de violencia o coerción, siempre y cuando la fuerza coercitiva sea administrada por el Estado.

Por otro sesgo debe introducirse el concepto psicoanalítico de la repetición. FREUD comenta que en el desarrollo psíquico del individuo existen determinados instintos egoístas que tienden a la satisfacción de placeres particulares, pero que dichos "instintos malos" pueden ser transformados desde el interior por una necesidad de amor, y desde el exterior por la coerción de la educación. Pero no es suficiente que el sujeto internalice dicha trasformación, es necesario que esté dispuesto siempre a comportarse en sociedad, de tal forma que no acuda a sus instintos egoístas. Por ello concluye Freud que "(...) La civilización ha sido conquistada por obra de la renuncia a la satisfacción de los instintos y exige de todo nuevo individuo la repetición de tal renuncia.

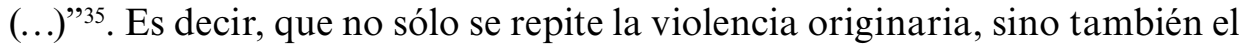
sometimiento a la misma.

Tenía razón MARX cuando, siguiendo a HegEL, decía que todos los grandes hechos de la historia siempre aparecen dos veces, una vez como tragedia y otra como farsa ${ }^{36}$ o comedia. Ello es así, en tanto que la repetición se efectúa mediante un procedimiento semiótico según el cual el signo lingüístico (la palabra- la ley) representa a un sujeto (el sujeto de derecho) o a un objeto (la violencia como ente) para otro significante (la realidad actual de los sujetos) ${ }^{37}$, pero esta representación nunca será como el original representado.

La repetición, por estar en el ámbito del lenguaje, se produce en el registro simbólico, esto es, en el del derecho. Mediante la repetición se busca repetir, valga la redundancia, lo real de la violencia fundadora, pero ésta es irrepresentable, en tanto que tiende a anular el derecho existente y crear uno nuevo. Por ello la violencia fundadora sólo puede estar al principio del derecho, y no se puede repetir formalmente dentro de éste, sino fuera. La violencia funda-

33 En el texto citado se sigue a Salvo Zizek. En Porque no saben lo que hacen, el goce como factor político. Pág. 273.

34 Ronald Zuleyman Rico Sandoval. Genealogía del concepto de poder constituyente primario en Colombia. Págs. 115 a 116. Tesis de grado para optar al título de abogado en la Facultad de Ciencias Jurídicas de la Pontificia Universidad Javeriana. (2005). Director, Juan Felipe García Arboleda.

35 Sigmund Freud. "Consideraciones de actualidad sobre la guerra y la muerte". En El malestar en la cultura y otros ensayos. Ob. cit. Pág. 104.

36 Carlos Marx. El dieciocho de brumario de Luis Bonaparte. Traducción del Instituto de MarxismoLeninismo de obras escogidas de Carlos Marx. Editorial Grijalbo. México. (1988).

37 Véase Jacques Lacan. Seminario 11. 
dora siempre se escapa a su simbolización (expresión en términos jurídicos, o lingüísticos), por lo que sólo se presenta como una farsa. Pienso aquí el término marxiano de farsa bajo el trasfondo lacaniano, esto es, como objet petit $a$, es decir, como sustituto que representa el núcleo de goce: bien sea la violencia como estallido racista violento (coercible por el derecho), o la violencia simbolizable, expresado en términos jurídicos.

Teniendo en cuenta lo anterior, puede pensarse ahora a modo de ejemplo, en el entorno del derecho civil, que si bien parte de la voluntad particular en la génesis de los contratos, no admite el instinto egoísta de negarse a cumplir lo pactado, pues en dicho caso siempre se presenta un núcleo violento que tiende a doblegar al contratante incumplido, y por ende, a la aniquilación de las pretensiones del sujeto violentado.

Así lo expresa, verbi gratia, un reconocido tratadista de derecho civil-obligaciones: "LA EJECUCIÓN coactiva o forzada es la primera y más importante atribución del acreedor frente al deudor incumplido. Es nítida manifestación del efecto de constreñir al deudor al pago porque supone (...) el empleo de la coacción misma del Estado con miras a lograr del deudor la prestación". 38

BENJAMIN, al analizar esta posibilidad de coacción jurídica, niega incluso que la voluntad pacífica de los contratantes sea garantía exclusiva de la ausencia de violencia: “(...) Pero ante todo,-dice BenJAMIN-debe precisarse que de un contrato de derecho no se deduce jamás una resolución de conflictos sin recurso alguno a la violencia. En realidad, tal contrato conduce en última instancia, y por más que sus firmantes lo hayan alcanzado haciendo gala de voluntad pacífica, a una violencia posible. Porque el contrato concede a cualquiera de sus partes el derecho de recurrir a algún tipo de violencia en contra de la otra en caso de que sea responsable de infracción a sus disposiciones. Y eso no es todo: el origen de todo contrato, no solo su posible conclusión, nos remite a la violencia. Aunque su violencia fundadora no tiene por qué estar inmediatamente presente en el momento de su formulación, está representada en él bajo forma del poder que lo garantiza y que es su origen violento, y ello sin excluir la posibilidad de que ese mismo poder se incluya por su fuerza como parte legal del contrato. (...)"39.

El acreedor imita la violencia originaria cuando la emplea en su contraparte, y actúa tal y como si fuera el soberano, de la forma como el Estado le ha permitido actuar, por ejemplo, ejecutando a su deudor, y no contento con ello, sometiéndolo a la violencia, legal pero residual, de las diligencias de embargo y secuestro, de lanzamiento o entrega de los bienes de éste para satisfacer el goce pleno del actor.

38 Jacques Cubides Camacho Obligaciones. Pág. 263. Pontificia Universidad Javeriana, Facultad de Ciencias Jurídicas. Bogotá. (1999).

39 Bejamin, Ob. cit. Pág. 33. 
Pensemos por este sesgo en la violencia de la propiedad privada. Ya en el acápite anterior se vio que la propiedad es necesaria, pues ella tiene un papel importante en el juego intersubjetivo que constituye la identidad de los sujetos deseantes. No obstante, si se quiere ir más lejos en este objetivo de analizar la violencia, debe considerarse no sólo que el origen de la propiedad está mancillado por una violencia fundadora, sino que, incluso, en determinados períodos de la historia la aparición de nuevos ricos ${ }^{40}$, o de nuevos propietarios, va aparejada de una violencia conservadora que se presenta mediante la inclusión, en las estructuras jurídicas, de los elementos coercitivos que hagan respetar ese objet petit a de quien ostenta la propiedad nueva.

Recuérdese que mediante la conquista se imponía el derecho de los vencedores a los vencidos, permitiendo la ocupación lícita. La "guerra justa" es la que se despliega contra infieles e idólatras, y ella fue la que se gestó en la conquista de América, tal y como lo expone Luis Hernando AristizÁbal Arbeláez siguiendo al historiador Francisco López de Gomara. En sus Anotaciones sobre derecho indiano, ARISTIZÁBAl cita las cartas de la conquista de México de Hernán Cortés para exponer la crueldad de la conquista: “(...) aunque ellos huían cuanto podían, embestimos por medio dellos, y quebramos infinitas canoas y ahogamos muchos enemigos, que era la cosa del mundo más para ver"4l.

En otro aparte AristizÁbAl expone: "El padre Francisco de Vitoria concibió toda una teoría de la ocupación de los nuevos territorios como 'res nullius', cosa sin dueño, por estar habitada por razas inferiores. Vitoria afirma la licitud del asentamiento español en las Indias, basándose también en la necesidfad (sic) de defender a los débiles e inocentes contra los abusos de los poderosos y en el hecho de que los pueblos americanos eran parte de la sociedad universal y que por lo tanto tenían que incorporarse a aquella sociedad para gozar de sus mismos beneficios e instituciones ("Relecciones teológicas")" "42.

La referencia a la res nullius no es ajena al derecho privado, que en el Código Civil, artículo 699, la consagra como las cosas sin dueño que son susceptibles de apropiación mediante la ocupación. Otro modo originario de adquirir el dominio que envuelve, a lo menos en el derecho colombiano, una manifestación violenta es la prescripción adquisitiva extraordinaria

40 Véase Juan Felipe García Arboleda. Voluntad de obediencia. La imaginación jurídica del cambio de régimen penal de la Nueva Granada en el siglo XIX. Tesis de grado para optar al título de abogado en la Facultad de Ciencias Jurídicas de la Pontificia Universidad Javeriana. (2002). Director Óscar Guardiola-Rivera. Así mismo véase Medófilo Medina. "La violencia en Colombia: inercias y novedades 1945-1950, 1985-1988". En Revista colombiana de sociología - Nueva Serie. Vol. 1. Enero - junio. (1990). Págs. 49 a 74.

41 Luis Hernando Aristizábal Arbeláez. Anotaciones sobre derecho indiano. Pág. 44. Pontificia Universidad Javeriana, Facultad de Ciencias Jurídicas. Bogotá. (1993).

42 Ibid. Pág. 55. 
por posesión violenta. Recuérdese que la usucapión es un modo por virtud del cual quien posee un bien puede adquirir el derecho de dominio sobre el mismo por el trascurso del tiempo. La regla general es que la posesión debe ser regular, esto es, que se ostente un justo título y se posea de buena fe. No obstante, una de las modalidades de la posesión irregular (aquella en que faltan los mentados requisitos) es la que se produce por medios violentos, es decir, "la que se adquiere por la fuerza", según preceptúa el artículo 772 del Código Civil.

Esta clase de posesión viciosa, que el derecho romano no reconocía como generadora del derecho de dominio por usucapión, es aceptada en nuestro medio jurídico por la Corte Suprema de Justicia "para prescribir en forma extraordinaria" $"$.

Y llegados a este punto del presente ensayo, valga la pena citar una brevísima contextualización del surgimiento del Código Civil en Francia, que denota ese tránsito violento al que se ha hecho referencia:

"En síntesis, dicho proceso (la abolición del feudalismo a raíz de la Revolución francesa) se inició en la Asamblea Nacional Constituyente con una transacción con la nobleza, continuó en la Asamblea Legislativa, la cual intentó aplicar justicia entre nobles y labriegos y culminó en la Convención nacional, la cual expropió totalmente a la nobleza a favor de los campesinos.

Por esto es cierto decir que la Revolución Francesa le dio al labriego la libertad del suelo, pues además en ellas se confiscó a los nobles y a la Iglesia las tierras, las cuales pasaron a ser bienes nacionales, los que posteriormente fueron subastados entre campesinos o donados a los soldados de la revolución y produjo como resultado que millares de hombres adquirieron propiedad sobre la tierra, lo que constituyó el aporte socio-económico más importante de la revolución.

Esta fue la situación jurídica de la propiedad cuando se estaba gestando y discutiendo el Código Civil Francés y esta también fue una situación que influyó y sirvió de vaso comunicante en los otros países europeos, quienes en una $u$ otra forma fueron eliminando las instituciones feudales de privilegio para unos pocos mediante el sacrificio de muchos" ${ }^{\prime 4}$.

Las anteriores citas permiten concluir, con MARX, que a pesar de que se suela considerar usualmente el origen jurídico de la propiedad, ello no significa que no exista un núcleo violento que lo respalde. Recuerda MARx que “(...) en la historia real desempeñan un gran papel la conquista, el esclavizamiento, el robo y el asesinato, la violencia, en una palabra. Pero en la dulce economía política ha reinado siempre el idilio. Las únicas fuentes de riqueza

43 Luis Guillermo Velásquez Jaramillo. Bienes. Pág. 138. Ed. Temis, Bogotá. (2000).

44 ERnesto PeÑa QuiÑónez. La propiedad - su evolución histórica régimen constitucional colombiano. En Universitas. $\mathrm{n}^{\circ}$ 83. noviembre de 1992. Facultad de Ciencias Jurídicas de la Pontificia Universidad Javeriana. Pág. 423. 
han sido desde el primer momento el derecho y el 'trabajo', exceptuando siempre, naturalmente, 'el año en curso'. En la realidad, los métodos de la acumulación originaria fueron cualquier cosa menos idílicos" ${ }^{\text {"45 }}$. En este mismo sentido, pero en otra oportunidad, MARX describió la gran transformación que sufrió la legislación civil que inicialmente respondía al reconocimiento de los derechos (libertad, igualdad y fraternidad), hacía, en la actualidad, la protección de los grandes capitales, en perjuicio de quienes sólo tenían su fuerza de trabajo en su patrimonio, y que terminaban, de una forma u otra, sin poder -jurídico- para defender lo que consideraban como suyo. En este sentido, y luego de contextualizar el gran desarrollo de la Revolución, y de efectuar un seguimiento a Luis Bonaparte y la situación francesa de mediados del siglo XIX, señaló MARX que “(...) El Code Napoleón no es ya más que el código de los embargos, de las subastas y de las adjudicaciones forzosas" ${ }^{\text {"46. }}$.

En la percepción acotada puede verse cómo la legislación civil, que se suponía entraría a regular las disputas entre sujetos por sus derechos conllevó al afianzamiento, en determinados casos, de un individuo que se suponía superior a otro, respecto del cual tenía la posibilidad no sólo de explotar, sino además, de obtener sus bienes. Piénsese, si se quiere, en la figura del agiotista, muy común en nuestro medio, aunque repudiada por el derecho: el prestamista, aquél que presta, como vulgarmente se dice "gota a gota", suele aprovecharse de la necesidad del deudor, y sin que quede registro de su usura, frente al incumplimiento de alguna de las cuotas pactadas suele ejecutar a su contraparte, para lo cual existe una estructura jurídica que establece un juicio ágil, que permite no sólo el embargo y secuestro de los bienes del deudor, sino también el remate de los mismos, en términos muy $\operatorname{cortos}^{47}$.

Y existen casos, conocidos de autos por los abogados litigantes, en los cuales el usurero, según el dicho de su ejecutado, no cobra directamente sino que la base de su ejecución lo constituye un título valor que es endosado a un tercero que cobra, lo que genera una barrera casi infranqueable ante la cual el ejecutado poco puede hacer, pues si no logra acreditar la mala fe o que la buena de su contrincante no está exenta de culpa, como lo expone el numeral 12 del artículo 784 del Código de Comercio, no habrá mayor consideración que impida su ejecución. Desde luego, en dichos términos la forma de acreditar la usura resulta una lid quijotesca.

Más aún, en las diligencias en que se practican medidas cautelares o se ejecuta una orden de lanzamiento, la autoridad respectiva en algunos casos

45 Carlos Marx. La génesis del capital. Pág. 4. Traducción de Editorial Progreso. Moscú. (1977).

46 Marx. El dieciocho brumario de Luis Bonaparte. Ob. cit. Pág. 150.

47 La celeridad en el trámite de los procesos ejecutivos fue una de las características de la reforma introducida al Código de Procedimiento Civil por la Ley 794 del 2003. 
no permite que las personas afectadas la interrumpan, con lo cual se logra "desplazarlos desde el punto de vista psicológico"48.

No se desconoce aquí la legalidad del juicio ejecutivo ni se pretende hacer una valoración moral, pues como quedó establecido al inicio de este ensayo, el objeto del mismo es cuestionar los límites del derecho y no sobre sus fines o valores.

En el orden de las ideas que se han venido exponiendo en este acápite se puede concluir, junto a RoBert COVER, que la violencia del derecho es más evidente si se observa desde el punto de vista de quien la sufre ${ }^{49}$.

El que sufre es quien ostenta la posición de debilidad en una relación jurídica: el mutuario frente a la entidad financiera cuando suscribe un contrato por adhesión de préstamo de dinero; el beneficiario de un contrato de seguros frente a la compañía aseguradora cuando pretende reclamar una indemnización; el arrendatario que se ve conminado a dejar el inmueble para entregarlo a su arrendador. Los anteriores son sólo eventos en los cuales un sujeto puede estar en posición de inferioridad frente a su contraparte contractual, sin que el ejemplo en sí se erija en todos los casos como el paradigma de violencia contra un sujeto dominado.

Pero la posición del sufriente no se limita a los sujetos de una relación jurídica sustancial o procesal, pues en señalados casos una determinada actuación jurídica puede afectar a terceros. Piénsese que una medida cautelar de embargo y secuestro puede afectar no sólo al deudor ejecutado sino también a su familia. En el ejercicio profesional abundan las historias respecto de las diligencias cautelares, en las cuales los menores y otros familiares del deudor manifiestan su sufrimiento de muchas formas, algunas denotando su impotencia frente al derecho como en el acto de llorar cuando ven sacar sus cosas; otras, en cambio, reaccionan violentamente frente al ejecutor de la medida ${ }^{50}$.

También se debe pensar en el sufrimiento simbólico, aquél que se produce cuando la medida coercitiva tiene una finalidad simbólica o social. Ello ocurre, por ejemplo, cuando el secuestro de bienes se realiza frente a una persona que tiene un estatus o nivel socioeconómico determinado y la presencia del personal que desarrolla la respectiva diligencia, en sí es un acto que profiere

48 Dicha afirmación me fue manifestada por quien en el año 2008, en el segundo semestre, fungía como las mayúsculas iniciales deben ir porque se trata del nombre propio del cargo juez once civil municipal de descongestión de Bogotá.

49 Robert Cover. "La violencia y la palabra". En Derecho, narración y violencia. Poder constructivo y poder destructivo en la interpretación judicial. Págs. 113 a 156. Traducción de Christian Courtis. Yale Law School, Universidad de Palermo, Facultad de Derecho y Gedisa editorial. Barcelona. (2002).

50 Tal situación me fue corroborada por la colaboración de jueces y litigantes amigos. Así por ejemplo, Sandra Lotero, abogada litigante, me manifestó que a pesar de no conocer directamente casos en que los afectados con medidas cautelares manifiesten inconformidad con las mismas, "sí lo he escuchado de colegas". De igual forma, en el segundo semestre del 2008, a un juez civil municipal de descongestión de Bogotá, en la práctica de una diligencia fue agredido con ácido en su rostro. 
humillación, pues esta persona queda expuesta al reproche social, situación que puede ser más transgresiva que la satisfacción de obligaciones con sus bienes $^{51}$.

Aquí no sobra pensar en el homo sacer ${ }^{52}$, aquella figura del derecho romano arcaico que rescató GioRgio AGAMBEN ${ }^{53}$, que representa al ser humano despojado de su humanidad. Es decir, aquel sujeto que no goza de todas las garantías jurídicas del ciudadano pleno, quien no tiene derecho a gozar ni acumular, y cuya situación particular es soslayada por el derecho, en tanto que éste formalmente atiende a las estructuras jurídico-económicas que otorgan un manto de legalidad a la violencia que se le inflige al sujeto dominado.

Pero la violencia que reparte el derecho tiene matices: en algunas ocasiones puede ser considerada de una intensidad leve como cuando establece no escuchar, en un acto procedimental, a un sujeto procesal como en el proceso de restitución de inmueble arrendado ${ }^{54} \mathrm{o}$ en las diligencias de secuestro que no admiten oposición del deudor o de su causahabiente ${ }^{55}$; en otras ejerce una fuerza jurídica mayor, ejecutada de forma legal y sin que sea considerada como arbitraria, pero que sitúa en una posición de humillación a un sujeto determinado, tal y como si fuera un homo sacer.

\section{EROS Y THÁNATOS}

FREUd oponía a la violencia (de la guerra) el amor, como ligazón estructurante de lazos sociales. Por su parte, BENJAMIn suponía que en las relaciones privadas de los hombres existían medios no violentos para solucionar sus conflictos, acudiendo a la cultura de los sentimientos que pone a disposición de los hombres "medios puros de entendimiento".

Sin embargo, si hemos de ser congruentes con lo expuesto hasta aquí, se ha de entender que el amor también es violento, es decir, también es un acto transgresivo que implica la renuncia a una demanda particular del sujeto. El amor en términos lacanianos no se edifica como una fantasía en la que sólo

51 Tuve la oportunidad de conocer la situación particular de una mujer, cuyo proceso ejecutivo ya estaba en etapa posterior a la sentencia, y quien me manifestó su indignación y su profundo temor de que se le realizara la diligencia de embargo y secuestro de bienes. Su impotencia frente a la inminencia de la misma era inocultable. Dejo claro que la mayoría de los ejemplos aquí referidos son extractados de la experiencia adquirida en la rama judicial, principalmente como juez civil municipal, pero también de la experiencia compartida de otros funcionarios.

52 Recuerda Freud, en Tótem y tabú, que la palabra polinesia tabú equivale al sacer de los romanos, y que éstas indican, de forma ambigua, lo sagrado, pero además lo inquietante, lo peligroso, lo prohibido, en otras palabras, lo impuro.

53 Giorgio Agamben. Homo sacer. El poder soberano y la nuda vida I. Traducción de Antonio Gimeno Cuspinera. Pre-textos, España. (2003).

54 Código de Procedimiento Civil. Artículo 424.

55 Código de Procedimiento Civil. Artículo 686. 
creemos que amamos, sino que va más allá al punto de reconocer lo real del otro, y amarlo no a pesar de sus defectos, sino además, por ellos ${ }^{56}$.

Ello no quiere decir que el amor tenga el mismo estatuto violento del derecho, sino que puede ser visto como la violencia "pura" de que habla WALTER BENJAMIN, esto es, aquella que aceptando la jouissance del otro permite una ruptura en el plano simbólico del derecho y crea nuevas subjetividades jurídicas. En otras palabras: el amor conlleva una trasgresión voluntaria en la que el deseo/goce propio se autorregula y cede para dar cabida al goce del otro.

Para entender esta violencia "pura" hay que leerla de cara a la violencia mítica ya comentada, puesto que aquella existe en la medida en que está excluida de ésta. Es decir, que la violencia pura está incluida dentro del orden jurídico por vía de su exclusión. Por ello la apuesta de una violencia pura o emancipadora se da en los límites del derecho, para establecer un nuevo nomos jurídico. Piénsese en el poder reestructurador del derecho que tiene el constituyente primario, que en un acto soberano de amor decide participar en conjunto como "sociedad" estableciendo un nuevo parámetro normativo diferente del anterior reformado.

La enseñanza que deja, entonces, el psicoanálisis al derecho es que no sólo debemos reconocer el origen violento del ordenamiento jurídico (de la ley) sino la estructuración violenta del mismo, puesto que gracias a una renuncia del goce y la implantación de un sistema normativo es posible la vida en sociedad. Pero esta renuncia no puede experimentarse como una imposición externa, pues la pulsión retorna, y el deseo de muerte, es decir, de luchar contra la sociedad, se vuelca nuevamente contra el derecho. La renuncia debe ser voluntaria, no en el sentido de obediencia voluntaria al derecho que expresa Kelsen, sino en cuanto a ser conscientes de dicha renuncia, y así repetirla constantemente en pro de la sociedad, como lo sostiene FREUD ${ }^{57}$.

La matriz, entonces, es que el derecho o el ámbito de la ley viene a establecer la prohibición fundamental que limita los deseos del hombre (que establece su excepción), pero que funciona además como la forma de incorporarnos al mundo simbólico de la red de relaciones sociales. El hombre, como animal social, para seguir la terminología zoológica de la sociología, no puede vivir en soledad, pero para poder vivir en sociedad debe aprender a respetar el deseo del otro, o a luchar por ese objeto de deseo de forma tal que el enfrentamiento no se reduzca a la eliminación del otro. Esta es la apuesta del derecho, establecer formas de violencia controladas que diriman los conflictos entre los diversos sujetos deseantes y que no conduzcan a la muerte del otro.

56 Sobre el particular puede verse, entre muchos otros textos, SLavo Zızek. Amor sin piedad, hacia una política de la verdad. Traducción de Pablo Marinas. Editorial Síntesis. España. (2001).

57 Freud llama, en el texto citado sobre la guerra y la muerte, al obedecer ciegamente las normas que limitan el goce instintivo un acto de hipocresía permanente, puesto que se aceptan sin que voluntariamente se deseen. 
Este "nuevo" derecho producto de la violencia del amor no es igualador como el discurso del amo que no admite goces diferentes al suyo, ni tolerante como el discurso multiculturalista que admite la jouissance del otro siempre que esté a una distancia prudente que no atosigue el goce propio ${ }^{58}$. La apuesta aquí es por una política de la verdad en que reconocemos nuestro sinthome, nuestro núcleo estructurador, que si bien plantea diferencias en cuanto a la forma como se ha de administrar el goce particular (mi yo frente a los otros), la solución del conflicto que se genere no se dirige a la eliminación de esas diferencias, sino al reconocimiento de las diversas formas de goce como integrantes de la sociedad. En suma, el sujeto de derecho no puede ser el sujeto cartesiano de los derechos humanos "sin distingo de sexo, raza, etc." sino el sujeto de deseo con una historia, una cultura, un sexo, una raza, y en general con todas las características que lo constituyen en sujeto.

Por lo anterior, el psicoanálisis lacaniano le apuesta al reconocimiento del mundo simbólico como la forma en que se ha de sobrevivir en comunidad, pero siendo conscientes de que en cualquier momento se puede presentar la implantación de una nueva ley simbólica que entrará a regir los designios de la vida psíquica del sujeto. Así funciona la ley del deseo, en un constante tire y afloje, o en términos deleuzianos, en un flujo de desterritorialización y reterritorialización. Este flujo del deseo sólo es posible en tanto que éste no puede ser limitado, y ello es así porque no hay cerrazón posible.

El derecho en sí no es un cuerpo coherentemente cerrado que tenga todas las respuestas para todos los conflictos. Ello se evidencia en la necesidad de establecer teorías de interpretación frente a los constantes vacíos de la ley, y en sí fundamenta la función de placebo de la reforma ${ }^{59}$.

Como colofón, los operadores jurídicos deben reconocer la insuficiencia del derecho para generar una coherencia que permita el establecimiento de normas de convivencia, cuya simple obediencia genere la vida en condiciones de tranquilidad, y por ello la reapropiación originaria de la fuerza es un mecanismo constante frente a las demandas particulares o luchas de seres deseantes. Pero esta insuficiencia que genera insatisfacciones de toda índole, es la que permite en los intersticios del mismo derecho la reapropiación de formas de violencia con posibilidades de estructurar un nuevo derecho, que desde luego no está exento de tener las mismas limitaciones del anterior.

58 Véase entre muchos textos de ZIZEK "Multiculturalismo, o la lógica cultural del capitalismo multinacional”. En Fredric JAMESON \& Slavoj Zizek. Estudios culturales. Reflexiones sobre el multiculturalismo. Traducción de Moira Irigoyen. Paidós. Argentina. (2005).

59 Sobre esta función de la reforma véase la parte segunda de La genealogía del poder constituyente primario en Colombia, obra ya citada. 


\section{A LAS PUERTAS (DEL “CUARTO DE MÁGUINAS”) DE LA LEY}

La referencia al concepto deleuziano que titula este acápite es más formal que teórica. Permítaseme esta apropiación conceptual en el siguiente sentido: tal y como lo destacaron Gilles Deleuze y Félix Guattari ${ }^{60}$, las máquinas funcionan mediante engranajes de diferentes piezas, todas ellas que interactúan con las otras en la consecución de un fin específico, aquel que se haya programado.

En el contexto sociosimbólico se pueden distinguir dos clases de máquinas: las máquinas sociales que se estructuran en torno a sistemas económicos de producción, y las máquinas deseantes que se estructuran en torno a la producción de deseos.

El derecho, como aquí se ha expuesto, se proyecta como un dispositivo violento establecido por una máquina social para regular sistemas de producción: la propiedad, el capital, cómo se adquieren éstos, cuál es la forma en que se deben resolver las disputas con respecto a los medios de producción, etc.

No obstante, también puede ser concebido como un dispositivo violento que las máquinas deseantes pueden utilizar, que en la forma como aquí se ha propuesto puede ejemplificarse en la apropiación del lenguaje jurídico por parte de sujetos que han sido puestos en condición de homo sacer.

Esta estructuración de las máquinas deseantes se efectúa "ante las puertas de la ley", tal y como KAKFA lo ejemplificó al finalizar el capítulo IX de El Proceso, esto es, como seres "afuera" de la ley, pero inmersos por vía de su exclusión. Los sujetos no pueden entrar a -ser partes a plenitud de-la ley, pero ésta está establecida para ellos, de tal suerte que una vez entran la "puerta" tiene que ser cerrada. No se puede dudar de la ley, puesto que "no se está obligado a creer cierto todo lo que dice; basta que se lo tenga como necesario". ${ }^{61}$

El derecho, la ley, no es algo que se presente como una forma natural que cobija a todos los sujetos, sino que es un ente creado para que exista la sociedad, es decir, que mediante el pacto de renuncia al goce se puede pertenecer a la sociedad, de lo contrario, se está por fuera del derecho, a las puertas de

60 La referencia a Deleuze tampoco resulta arbitraria. Si bien se conoce la oposición que él planteó al psicoanálisis de su época, desde mi interpretación la principal objeción planteada radica en la práctica de algunos psiquiatras, más que en la conceptualización freudo-lacaniana aquí expuesta. Sin embargo, para un análisis más detallado sobre la filosofía deleuziana contrapuesta a la del psicoanálisis verse Slavou Zizek, Órganos sin cuerpo. Sobre Deleuze y consecuencias. Traducción de Antonio Gimeno Cuspinera. Pre-textos. España, 2006. En dicho texto Zizek demuestra que la oposición Deleuze - Lacan no es tan radical y su interrelación tampoco es imposible.

61 Franz Kafka. El proceso. Pág. 205. Traducción de Vicente Mendivil. Ed. Losada S.A. Argentina. 1980. 
la ley. Por ello, quizás, parafraseando a KAFKA, el derecho no quiere nada de los sujetos, sólo los toma cuando vienen a él, y los deja cuando se van.

Pero este estar afuera de la ley no puede verse simplemente como una renuncia solus ipse de la ley, es decir, un individuo en su soledad no puede desechar el derecho, puesto que el mismo llega para reprender cualquier perturbación del "orden legal". Así el sujeto que desconozca la fuerza estructurante del derecho y se retraiga del cumplimiento de la ley, por ejemplo, al hurtar un bien a otro sujeto, se verá castigado por la violencia del derecho estatal.

Sin embargo, si lo que se presenta es una articulación social que pretenda desconocer el derecho imperante, ésta puede ejecutar actos tendientes a la modificación de la estructura violenta que se repele (o el derecho estatal con el cual no se está conforme). Para ello la referencia kafkiana tiene una mayor relievancia, en el sentido deleuziano de una desterritorialización "menor", es decir, que las voces "menores" dentro de un cuerpo social (o máquina social) pueden estructurarse como cuerpo o máquina deseante, esto es, como articulación política con la intención de generar un desplazamiento del lenguaje y una reterritorialización del mismo. En otras palabras, la articulación en un cuerpo social puede tender a generar un cambio en la percepción de los significantes (jurídicos) que posibiliten la inclusión de quienes no se sienten partícipes de la ley, y por ende, que posibiliten un acercamiento al deseo del otro $^{62}$.

Piénsese con BenJAmin, en la violencia de la huelga general, un medio violento regulado por el derecho, establecido para posibilitar el diálogo entre empleador y trabajador para la estructuración de un ordenamiento jurídico particular que normalice (regularice) sus relaciones.

Pero piénsese además en los sujetos cuyo goce difiere del regulado por las estructuras clásicas del derecho, y se proyectan como constituyente primario para trasformar el entorno de su subjetividad, como ocurrió en Colombia con la constituyente de 1991. Aquí la referencia al problema del género y la identidad sexual también resulta de recibo: la violenta imposición de la ley de cuotas se interpretó por la Corte Constitucional como la aplicación de una "acción afirmativa" que genera una desigualdad para propiciar una igualdad, esto es, que las mujeres por su condición de tales no se vean discriminadas a la hora de acceder a un cargo de dirección. Por otro sesgo, también se encuentran en este espacio las políticas públicas para la comunidad LGTB (lesbianas, gays, transgeneristas y bisexuales), cuya finalidad primordial es la de "introducir" en el mundo jurídico la jouissance de "esos" otros diferentes.

62 Véase Gilles Deleuze \& Felix Guattari. “¿Qué es una literatura menor?”, capítulo III. En Kafka. Por una literatura menor. Traducción de Jorge Aguilar Mora. Ediciones Era S.A. México. (1978). 
Este reposicionamiento de ciertos sujetos en el espacio de la ley pone de presente la vitalidad obscena que impregna al derecho, como un "bricolaje heterogéneo, inconsciente, penetrado de goce" ${ }^{63}$.

Todo lo anterior permite concluir que el núcleo del derecho, su centro violento, es un punto de goce, cuya estructura es la del superyó. El superyó se presenta como una instancia inconsciente que bajo el ropaje de la permisión bloquea el acceso al goce ${ }^{64}$. Es decir, el núcleo violento del derecho se presenta accesible a todos los sujetos deseantes, con la condición de que nadie puede acceder a él, pues de lo contrario, se ha de sentir el peso represor de la violencia estatal que imposibilita el goce. Pero como quiera que el acto de lucha en el seno de una articulación social implica la renuncia a un pedazo de goce, a efectos de consolidar una reescenificación de la sociedad, las máquinas deseantes han de asumir un acto ético, un acto heroico, en el sentido de perseguir un ideal o un principio fundamental "más allá del principio de placer", sin consideración a la violencia conservadora que el derecho le pueda propinar.

\section{EL CUARTO de MÁguINAS JUdicial}

Para finalizar este ensayo, quiero relievar la importancia de los dispositivos jurídicos judiciales establecidos por la máquina social mediante la exposición de la dimensión interpretativa que expone Cover en su texto antes citado. Dicha dimensión se caracteriza por ser i) una actividad práctica ii) diseñada para generar amenazas creíbles y actos de violencia reales iii) de un modo efectivo. Básicamente las decisiones judiciales son prácticas en sí mismas porque envuelven órdenes para otros que las deben cumplir. Ello se evidencia en tanto que, aun cuando las personas sientan fascinación o repudio por formas de violencia, la conciencia individual sucumbe ante una orden de violencia cuando obedece un mandato u orden sancionada institucionalmente ${ }^{65}$. La efectividad, así, de la violencia jurídica estatal se logra en la medida en que la interpretación judicial tiende a transformarse en acción, esto es, en tanto se materializa en la forma prevista, pero además, ejerciendo tal violencia que reprima o inhiba la represalia o la venganza contra el ejecutor o el ordenador de la decisión de violencia, mediante el acatamiento por parte del que sufre los efectos de la misma.

En las diligencias de embargo y secuestro de bienes, por regla general, la persona que las atiende no muestra mucha resistencia, sino que acepta las

63 Slavoj Zızek. Mirando al sesgo. Ob. cit. Pág. 246.

64 Slavoj Zizek. Porque no saben lo que hacen. Ob. cit. Pág. 309.

65 No sobra aquí la referencia a la famosa investigación de Stanley Milgran, en donde se investigó a gente del "común" que aceptaba aplicar choques eléctricos (falsos pero que creían verdaderos) a estudiantes voluntarios cuando éstos respondían mal algunas preguntas, siempre que ello fuera en acatamiento de la instrucción de alguna figura de autoridad. 
mismas cuando el juez que las practica se identifica como tal. De otro lado, en tanto que entre las partes de una relación jurídica puede ser agresiva, en términos verbales o físicos, si la coacción está amparada por una decisión de una autoridad judicial, ésta tiende a ser obedecida por quien la sufre.

No obstante lo anterior, por convicciones morales más que políticas, muchos de los jueces con quienes he compartido mi interés en estudiar la violencia jurídica han manifestado su desacuerdo con algunas de las actuaciones que han desarrollado, e incluso algunos preferirían no tener que sacar los bienes del deudor de su casa o, mejor, lanzar al mismo de dicho sitio, pero en la práctica ninguno muestra resistencia, ni se niega a efectuar tal acto, por cuanto existe una orden judicial que hay que cumplir, en acatamiento de la ley.

En este ambiente de violencia jurídica, quien se encuentra padeciendo la determinación judicial puede optar también por ejercer otras formas de violencia, algunas legales, otras ilegales, y otras que considero se encuentran en una posición argumentativa intermedia. A continuación describo algunos ejemplos de las violencias referidas.

Lo que yo llamo "violencia legal" del afectado son los diferentes usos que el sujeto pasivo de una relación jurídica les da a los medios jurídicos legalmente establecidos, es decir, que esta violencia defensiva está inmersa en el aparato jurídico como un dispositivo violento aceptado. El ejemplo paradigmático lo centro en el uso de la acción de tutela como mecanismo no sólo defensivo, sino también dilatorio de actuaciones judiciales. Los jueces para la práctica de las diligencias tienen establecido un cronograma que atiende al orden de las peticiones y al cúmulo de trabajo, por ello cuando se acude a la acción de tutela, atacando una decisión judicial, usualmente se presta el expediente o la actuación particular al funcionario que va a fallar el recurso de amparo. Por manera que una acción de tutela, en el momento idóneo puede, a más de impedir que se efectúe una diligencia de las que se han referido aquí, retrasar considerablemente la misma mientras se señala una nueva fecha para realizarla.

Propongo el caso de la acción de tutela y no el de la proposición de recursos ordinarios dentro del proceso, por cuanto dicha actuación con fines dilatorios es considerada como una manifestación censurada y que a la vez es castigada por el ordenamiento procesal, en tanto que el amparo constitucional no tiene mayor censura que la actuación temeraria que se presenta cuando un mismo actor, por unos mismos hechos, interpone en más de una ocasión acción contra un mismo accionado, cuyo efecto directo es la negativa del amparo solicitado.

De otro lado, como "violencia ilegal" advierto entre otras facetas la agresión física: los encuentros entre la policía y una comunidad, en los cuales ésta arremete incluso empleando objetos contundentes, que están a la orden del día. En la década de los noventa, como es bien conocido, en Colombia se 
presentó una crisis económica y social: las tasas de interés se incrementaron en forma desproporcionada lo que generó un aumento en el pago de las cuotas de los créditos hipotecarios pactados bajo el amparo del antiguo sistema de financiación UPAC, puesto que el cálculo de esta unidad de cuenta estaba atada al flujo de las tasas de interés en la economía (DTF). Los deudores entraron en cesación de pagos y muchos procesos ejecutivos hipotecarios se adelantaron para el cobro de dichas deudas. Frente a la objetividad de la mora, no había mayores discusiones, y por ende la ejecución se adelantaba hasta el remate de los inmuebles gravados. En dicha época, ante la inminencia de las numerosas diligencias de entrega de predios rematados, los diferentes deudores se asociaron a efectos de impedir que se llevara a cabo el lanzamiento del ejecutado y su familia. El acompañamiento de la fuerza pública a las diligencias parecía ser la regla que se debía seguir, por los enfrentamientos que se presentaban.

Ahora bien, lo que yo considero "violencia argumentativa" es la que sin ser propiamente legal, no se manifiesta en forma de agresión física. Ésta se presenta cuando los afectados por la violencia de las medidas adoptadas por autoridades judiciales intentan apropiarse de un lenguaje técnico del derecho que les otorgue un manto aparentemente jurídico a sus reclamaciones. Pienso aquí en los numerosos eventos en que las personas que atienden las diligencias de secuestro o entrega, sin ser abogados, se oponen a las mimas en términos jurídicos. Así, dichas personas manifiestan que "esto es ilegal", "esto no es legal" o "esta diligencia es arbitraria". La apropiación de un lenguaje jurídico no implica la efectividad de sus demandas, pero sí la demora en la práctica de la actuación judicial y en esa medida puede leerse como forma de violencia a partir del lenguaje, como una salida de los problemas de los afectados, o al menos, como el medio de manifestar su inconformidad frente al sistema jurídico ante el cual está sometido.

Otro ejemplo de la apropiación del lenguaje jurídico lo presenta ROBERTO CARlos Vidal López al referirse a la estructuración de la relación estadodesplazado: los desplazados se ven obligados a modificar su lenguaje para hablar el de la ley, y por ello "(...) abandonan entonces las pretensiones de atención integral para mimetizarse en el lenguaje estatal: los desplazados luchan incansablemente por su derecho a tres meses de atención de emergencia y los equipos de aseo o cocina. (...)". Si bien la modificación del lenguaje propio es de por sí violenta (al abandonar las pretensiones propias), el desplazado aprehende el lenguaje del derecho, con lo que se apropia de un dispositivo violento para reclamar lo que considera suyo ${ }^{66}$.

66 Roberto Carlos Vidal López. Derecho global y desplazamiento interno. Creación, uso y desaparición del desplazamiento forzado por la violencia en el derecho contemporáneo. Pontificia Universidad Javeriana, Facultad de Ciencias Jurídicas. Bogotá. (2007). No dejo de pensar aquí que el lenguaje del desplazado es kafkiano, en el sentido de constituirse como un lenguaje "menor" inserto en la 
Lamentablemente la rutinaria actuación de las diligencias de embargo y secuestro o de entrega de bienes ha generado que las actas donde se consignan tengan una objetividad lingüística propia del lenguaje normativo, es decir, que se refieren a la situación particular sin tener en cuenta las condiciones que le dan vida propia, y pareciera por ello que todas las diligencias son exactamente iguales. Es decir, el lenguaje profiláctico deja de lado la vitalidad obscena del goce jurídico. Por lo anterior, el estudio de la violencia no puede ser preponderantemente documental, sino que debe relievar el dicho de los sujetos que participan en las diligencias, lo que de por sí genera una dificultad en la tarea del investigador, máxime cuando a la versión que es más fácil de acceder es la de quien ejecuta la orden de violencia jurídica.

sociedad que no admite una enunciación argumentativa en lenguajes diferentes. 


\section{CONCLUSIONES}

La primera conclusión que se ha de extractar es que la violencia del derecho no debe rastrearse exclusivamente en los "orígenes" del Estado, tema perteneciente a la ciencia política y al derecho público, ni en la potestad de castigar del Estado que estudia la ciencia penal, puesto que, como se señaló en este ensayo, la violencia genitora de la sociedad parte de la interrelación del sujeto con otros, en un entramado simbólico por la lucha del goce propio que se gesta mediante flujos de deseo y apropiaciones de diversos objet petit $a$. Es decir, la violencia fundadora del derecho se puede rastrear en el epicentro del derecho privado, en el derecho de propiedad, y se debe analizar, por tal motivo, la violencia que se mantiene o conserva en las diversas formas jurídicas establecidas para sostener dicho derecho.

Así mismo, debe considerarse que el derecho como dispositivo o herramienta maquínica es usado por las máquinas sociales y las máquinas deseantes. Aquí no se puede perder de vista que en el seno del derecho mismo siempre perdurará la posibilidad de la creación de un nuevo derecho que surge de la violencia "pura o revolucionaria", por la conjugación de pulsiones de los sujetos deseantes, en constantes flujos desterritorializadores. Es decir, no existe garantía alguna de que el derecho que sostiene simbólicamente las relaciones sociales impida el surgimiento de nuevas subjetividades con deseo de cambiar la estructura jurídica existente. La violencia que una vez fue, puede ser otra vez.

También se puede colegir, entonces, que el derecho conserva la estructura de la "deuda infinita" en el sentido en que los asociados deben repetir el gesto fundamental de renuncia a una porción de goce propio para que el derecho tenga vocación de permanencia. No obstante, dado que la violencia mítica, como lo expone WALter Benjamin, es en esencia estatal, la violencia jurídica que aplica se presenta como una imposición externa, en contraposición a la violencia pura de las máquinas deseantes-como cuerpos constituyentes-que se proyecta como una deuda de amor.

De igual modo, puede verse que la actuación de los operadores jurídicos conlleva una notable similitud con la "desautorización fetichista" de "lo sé muy bien, pero sin embargo ...". Así el operador sabe muy bien que puede estar impartiendo violencia (causando sufrimiento) a un sujeto, por ejemplo en un desalojo, sin embargo, actúa como si no lo hiciera. Ello en tanto que se transfiere al otro de la ley o del derecho el sentimiento de inconformidad que el operador siente, y así alivia su culpa.

Finalmente, y aun cuando ello no haya sido enunciado explícitamente, debo reconocer que el punto teórico de este ensayo se basó en los textos de Freud y Benjamin sobre la violencia. Dichos textos se sitúan espaciotemporalmente en Europa entre los años 1915 y 1932, es decir, en el período entre 
las dos guerras mundiales del siglo XX. Es diciente cómo la violencia termina siendo un referente obligado para áreas que al principio parecen disímiles como son el psicoanálisis y la filosofía (y el derecho) en un momento golpeado por una gran guerra y que pronto ve surgir el fascismo como ideología y el estado de excepción como regla general. Tal vez sea ésta la ideología, más que cualquier otra, de la cual quería depurar el derecho las investigaciones de Hans Kelsen que se adelantaron también en dicha época. No en vano, tanto Benjamin como Kelsen fueron contradictores de Schmitt, teórico de aquella ideología.

Por lo anterior resulta diciente, a la vez que extraño, que en la actualidad, donde la violencia parece imperar tanto en el ámbito local como en el internacional, los estudios sobre la relación entre el derecho y la violencia, en general y de cara a Colombia, se vean minimizados por percepciones particulares como son las violaciones de derechos humanos, la violencia intrafamiliar, o el acoso laboral, o que el único espacio donde los sujetos pueden aducir su condición de sujetos pasivos de actos violentos sea la victimología. Dicha minimización de los ámbitos de expresión de la violencia es de por sí ideológica, porque prescinde del antagonismo que subyace a la sociedad y que permite que la violencia jurídica no se presente como una instancia a la cual puedan acceder todos los sujetos para la satisfacción de su goce, sino como el dispositivo que mantiene relaciones de dominación del tipo amo-esclavo, sujeto activo-sujeto pasivo.

A pesar del lenguaje "puro", en el sentido de profiláctico, ha de reconocerse, al contrario de lo expuesto por Kelsen, que el derecho es violento, a la par que ideológico, ya que su núcleo lleva implícita una vitalidad obscena de goce, para efectos de poder entender los límites en que éste actúa, y así generar espacios que permitan la articulación de nuevas subjetividades jurídicas que no obliteren el antagonismo implícito, incluso en la normatividad que regula el derecho de propiedad. 


\section{BIBLIOGRAFÍA}

Giorgio Agamben. Homo sacer: el poder soberano y la nuda vida. Traducción de Antonio Gimeno Cuspinera. Pre-textos. España. (2003).

Luis Hernando Aristizábal Arbeláez. Anotaciones sobre derecho indiano. Pontificia Universidad Javeriana, Facultad de Ciencias Jurídicas. Bogotá. (1993).

Cesare Beccaria. De los delitos y de las penas. Textos fundamentales de derecho, núm. 2. $3^{\text {a }}$ ed. Universidad Externado de Colombia. Bogotá. (1995).

Walter Benjamin. "Para una crítica de la violencia". En Para una crítica de la violencia y otros ensayos. Iluminaciones IV. Traducción de Roberto Blatt. Editorial Taurus. España. (1999).

Judith Butler, Ernesto Laclau, Slavoj Zizek. Contingencia, hegemonía, universalidad. Diálogos contemporáneos en la izquierda. Traducción de Cristina Sardoy y Graciela Homs. Fondo de cultura económica. Argentina. (2004).

Robert Cover. "La violencia y la palabra”. En Derecho, narración y violencia. Poder constructivo y poder destructivo en la interpretación judicial. Traducción de Christian Courtis. Yale Law School. Universidad de Palermo. Facultad de Derecho y Gedisa editorial. Barcelona. (2002).

Jorge Cubides Camacho. Obligaciones. Pontificia Universidad Javeriana. Facultad de Ciencias Jurídicas. Bogotá. (1999).

Gilles Deleuze, Félix Guattari. Kafka. Por una literatura menor. Traducción de Jorge Aguilar Mora. Ediciones Era S.A. México. (1978).

Costas Douzinas. El fin de los derechos humanos. Traducción de Óscar Guardiola-Rivera, Ricardo Sanín Restrepo y Ómar Alonso Medina. Legis. Universidad de Antioquia. Colombia. (2008).

Sigmund Freud. "Consideraciones de actualidad sobre la guerra y la muerte". En El malestar en la cultura y otros ensayos. Traducción de Ramón Rey Ardid. Alianza Editorial. Colombia. (1988).

. "El malestar en la cultura". En El malestar en la cultura y otros ensayos. Traducción de Ramón Rey Ardid. Alianza Editorial. Colombia. (1988).

. "El porqué de la guerra". En Obras completas. Tomo III. Traducción de Luis López-Ballesteros. Editorial Biblioteca nueva. (1973).

"Tótem y tabú". En Obras completas. Tomo II. Traducción de Luis López Ballesteros. Editorial Biblioteca nueva. (1973).

Juan Felipe García Arboleda. Voluntad de obediencia. La imaginación jurídica del cambio de régimen penal de la Nueva Granada en el siglo XIX. Tesis de grado para optar al título de abogado en la Facultad de Ciencias Jurídicas de la Pontificia Universidad Javeriana. (2002). Director Óscar Guardiola-Rivera.

Franz KafKa. El proceso. Traducción de Vicente Mendivil. Ed. Losada S.A. Argentina. (1980).

Hans Kelsen. Teoría general del derecho y del Estado. Universidad Nacional Autónoma de México. Traducción de Eduardo García Máynez. México. (1995).

Teoría pura del derecho. Originalmente publicada en 1935. Editorial Losada 
S.A. Traducción de Jorge G. Tejerina. Buenos Aires. (1941).

JACQues Lacan, "Kant con Sade”. En Escritos 2. Traducción de Tomás Segovia. Siglo XXI editores. Argentina. (2003).

Seminario 11: los cuatro conceptos fundamentales del psicoanálisis. Traducción de Juan Luis Delmont-Mauri y Julieta Sucre. Ed. Paidós. España. (1987).

Diego Eduardo López Medina. Teoría impura del derecho. Ed. Legis. Bogotá. (2004).

Carlos Marx. El dieciocho de brumario de Luis Bonaparte. Traducción del Instituto de Marxismo-Leninismo de obras escogidas de Carlos Marx. Editorial Grijalbo. México. (1988).

Carlos Marx. La génesis del capital. Traducción de Editorial Progreso. Moscú. (1977).

Medófilo Medina. "La violencia en Colombia: inercias y novedades 1945-1950, 1985-1988". En Revista colombiana de sociología - Nueva Serie. Vol. 1. Enero-junio. (1990).

ERnesto Peña Quiñónez. "La propiedad - su evolución histórica régimen constitucional colombiano". En Universitas no 83. Nov. (1992). Facultad de Ciencias Jurídicas de la Pontificia Universidad Javeriana.

Ronald Zuleyman Rico Sandoval. Genealogía del concepto de poder constituyente primario en Colombia. Tesis de grado para optar al título de abogado en la Facultad de Ciencias Jurídicas de la Pontificia Universidad Javeriana. (2005). Director Juan Felipe García Arboleda.

Jorge Reinaldo Vanossi. Teoría constituyente, poder constituyente fundacional, revolucionario, reformador. Ediciones Desalma. Buenos Aires. (1975).

Luis Guillermo Velásquez Jaramillo. Bienes. Ed. Temis. Bogotá. (2000).

Roberto Carlos Vidal López. Derecho global y desplazamiento interno. Creación, uso y desaparición del desplazamiento forzado por la violencia en el derecho contemporáneo. Pontificia Universidad Javeriana, Facultad de Ciencias Jurídicas. Bogotá. 2007.

Slavoj Zizek. Amor sin piedad, hacia una politica de la verdad. Traducción de Pablo Marinas. Editorial Síntesis. España. (2001).

El frágil absoluto o ¿Por qué merece la pena luchar por el legado cristiano? Traducción de Antonio Gimeno. Ed. Pre-textos. Valencia. España. (2002).

. El sublime objeto de la ideología. Traducción de Isabel Vericat Nuñez. Siglo XXI Editores. Argentina. (2003).

La suspensión política de la ética. Traducción de Marcos Mayer. Fondo de Cultura Económica. Argentina. (2005).

Mirando al sesgo. Una introducción a Jacques Lacan a través de la cultura popular. Traducción de Jorge Piatigorsky. Paidós. Argentina. (2004).

"Multiculturalismo, o la lógica cultural del capitalismo multinacional". En Fredric Jameson y Slavoj Zizek. Estudios culturales. Reflexiones sobre el multiculturalismo. Traducción de Moira Irigoyen. Paidós. Argentina. (2005).

Órganos sin cuerpo. Sobre Deleuze y consecuencias. Traducción de Antonio Gimeno Cuspinera. Pre-textos. España. (2006).

. Porque no saben lo que hacen. El goce como factor político. Traducción de Jorge Piatigorsky. Paidós. Argentina. (1998). 